\title{
THE PROPOSED UNIFORM COMMERCIAL CODE AS A PROBLEM IN CODIFICATION
}

\author{
FreDeRICK K. BeUTEL*
}

The knowledge of an English Lawyer is nothing but a beggarly account of scraps and fragments. His memory may be stored with numerous particulars, but of the law as a whole, and of the relations of its parts, he has not a conception. Austin. $\dagger$

To correct this condition still existing in America almost a century later, was one of the purposes behind the projected codification of the commercial law.

The proposed Uniform Commercial Code is probably the most important piece of business legislation ever prepared in the United States, if not in the world. It compares favorably in volume and subject matter with the French and German Commercial Codes. Because the Code is designed to have the force of law and control the major part of interstate mercantile and financing transactions, whereas the Restatement is non-official and has no more than advisory effect, it is more important than the American Law Institute Restatement of the Law.

The new Commercial Code, the product of very complete and important cooperation between the American Law Institute and the Commission on Uniform Laws, comes into being with the prestige and the promise of success assured by the joint efforts of these two great legal organizations. The fact that the Commission on Uniform Laws is willing to replace sixty years of successful effort in the creation and adoption of the Uniform Negotiable Instruments Law, the Warehouse Receipts Act, Sales Act, Bills of Lading Act, Stock Transfer Act, and other statutes which have succeeded in obtaining substantial uniformity of legislation in their field, shows that the commissioners have justifiable faith in the project.

For the purpose of this discussion the old quarrel between codification and noncodification as to which can establish the best system of law can be set aside. So far as uniform commercial laws are concerned, fifty years' experience has established the fact that codification is the only successful means to uniformity where so many separate jurisdictions are involved. The writer, from the beginning, ${ }^{1}$ has been one of the hardiest supporters of the project, and believes it feasible and the only present solution to the pressing problem of unifying the basic law of commercial

* A.B. 192I, Cornell University; LL.B. 1925, S.J.D. 1928, Harvard University. Professor of Law, University of Nebraska.

† II Lectures on Jurisprudence im (3d ed., Campbell, i869), Jerome Hall, Rieadings in JurisPRUDENCE 333 ( 1938 ).

${ }^{1}$ As far back as 1932 the writer recommended complete codification of the uniform commercial laws. Beutel, The N. I. L. Should Not Be Amended, 80 U. of PA. L. Rev. 368, 385 (I932); see also, Brannan's Negotiable Instruments Law 1124 (Beutel, 5th Ed. 1932); Beutel, The Proposed Bank Collection Act and Possibility of Recodification of the Law of Negotiable Instruments, 9 TuLANE L. REv. 378 (I935). 
transactions. It is the type of endeavor which deserves every success and the cooperation of the best talent that the legal and commercial field has to offer.

Since the Code is still in a very fluid state and particular provisions are subject to radical change at any time, the present discussion will be confined to general principles and broad outlines, using as a basis of reference the proposed final draft of the spring of $195^{\circ}$ as changed by the September revisions.

The policy behind the Code is superb, the only question remaining is the quality of the present product.

\section{I}

\section{Stonsoring Organization and Worring Personnel}

As indicated by the Comment to the title section of the Code, ${ }^{2}$ the project is the joint effort of the Commission on Uniform Laws and the American Law Institute. Its production is under the direct supervision of a drafting board headed by Judge Herbert F. Goodrich, Director of the American Law Institute. The actual drafting was done by members of the faculties of leading law schools who were individually designated to draft various sections. Each section has a group of advisers consisting of specially selected judges, practicing lawyers, and law teachers. The advisers meet with the draftsmen on frequent occasions to debate and alter the draft both as to substance and form. After a draft has cleared the advisers it is examined by the Council of the American Law Institute and either the Commercial Acts Section or the Property Acts Section of the Conference of Commissioners on Uniform Laws. Thereafter it is discussed in a joint meeting of the Commission and American Law Institute, where controversial matters are debated and settled in democratic fashion by a majority vote of those present. Then the Code returns to the draftsmen for further alteration in accordance with the results of the debate, and sometimes the process is' repeated. The proposed final draft contains about three pages ${ }^{3}$ with names of prominent lawyers, judges, and law teachers who are engaged in this process of codification.

Although the array of talent is very imposing, a careful examination of the process will show that most of these people have only casual connection with the Code. The pressure to complete the work within the five years prescribed by the financing foundation has been so great that the proposed drafts to be discussed in the larger meetings have usually come to the hands of the members only a few days before the gathering; and it is not uncommon for the agenda, draft, or subject of the debate to be handed to those present after they are seated in the committee rooms. Under these circumstances, since the members are all busy people, they have been able to give the drafts only casual examination. The debate that follows by the members of the drafting staff and those assembled for the discussion presents a one-

\footnotetext{
${ }^{2}$ Pp. 2ff. Proposed Final Draft, Uniform Commercial Code (Spring, r950). Unless otherwise designated, hereafter references to sections will be to this edition as corrected by September, 1950, Revisions of Articles 2, 4 and 9. Page numbers, unless otherwise indicated, will be to the Spring edition.

${ }^{3}$ See pp. $4-6$ inclusive.
} 
sided picture in which a completely prepared draftsman debates with necessarily unprepared members. The result has been that, even in shocking examples of errors in the Code, ${ }^{4}$ a majority of those present, being unacquainted with the subject of the debate, have almost always voted in favor of the proposed draft. Thus many errors in policy and draftsmanship which would have been exposed by a more complete study by the larger groups are approved for final publication under this one-sided procedure.

The real work of drafting and criticism is done by the smaller group of draftsmen and advisers under the direction of Professor Karl N. Llewellyn who has much experience in this type of work. ${ }^{5}$ It is upon their shoulders that the greater burden of creating a workable code must necessarily fall. In setting up this inner organization the plan of the American Law Institute, with only slight changes, has been adopted.

The eight or more draftsmen who are creating the Code, as set out in an earlier draft, ${ }^{6}$ all seem to be people who are or at some time have been law teachers. At the time of their appointment three had held full professorships, the rest were of lower academic rank. Five of the ten articles of the Code seem to have been in the direct charge of Professor Llewellyn ${ }^{7}$ and the remainder ${ }^{8}$ were drafted by the other seven under his supervision.

The draftsmen for each article have had a group of advisers totaling twentytwo individuals ${ }^{9}$ divided into committees of not over six or seven persons for each Article made up of judges, law professors, and practicing lawyers, many of whom served on more than one committee. The make-up of the various advisory groups seems to be as much on a basis of representation of membership in the Institute and the Commission on Uniform Laws as on the expert qualifications of the individuals chosen as advisers. These facts tend to concentrate even more upon the draftsmen the responsibility for the technical excellence of the Code.

The task of drafting a commercial code is more complicated and important than the work of merely restating portions of the common law. Not only must the draftsmen be entirely familiar with wide areas of the law as it exists, they must also be able to fashion an instrument for the regulation of a myriad of commercial situations both present and future which insures continuity of the law and business

\footnotetext{
4 Among others the provisions of Sections I-I05 and 1-I07 discussed below have been debated and approved at least once by close votes.

"Professor Llewellyn during his service on the Commission on Uniform Laws, drafted some amend. ments to the N. I. L. which were never approved; he is also the draftsman of the Trust Receipts and parts of many other uniform acts most of which are narrow statutes. His most famed writings are in the field of Jurisprudence; but he has published a case book in Sales.

The May, 1949, Draft contains the names of draftsmen and committees of advisers in the Comment to the first section of each Article. For example, see p. 35 (I949 Draft). In following the list the article numbers will have to be changed to correspond with the r950 draft.

${ }^{7}$ Sales, Lerters of Credit, Documents of Title, Miscellaneous Banking Transactions, and Bulk Transactions.

${ }^{8}$ Commercial Paper, William E. Prosser and Fairfax Leary; Bank Deposits and Collections, Fairfax Leary; Investment Securities, Soia Mentschikoff (Mrs. Llewellyn); Secured Transactions, Allison Dunham, Grant Gilmore, Charles Bunn, Fairfax Leary.

- For a list of these men see the 1949 Draft, supra note 6.
} 
practices, is sufficiently sharp to cut out injustice, and remains flexible enough to allow for legitimate change. This requires knowledge, skill, and insight which can only be furnished by a large and carefully manned research and drafting organization.

Even if this staff of workers were as numerous and able as those who compiled the Restatement ${ }^{10}$ it is highly doubtful if the same type of organization which did that work could prepare in five or six years a suitable commercial code when the first three volumes of the Restatement ${ }^{11}$ required over ten years for completion. ${ }^{12}$ It should also be noted that the compilation of the Commercial Codes of France ${ }^{13}$ and Germany ${ }^{14}$ which are comparable but not so difficult, each occupied for seven to ten years the best legal minds of those two countries.

In a project of the size and importance of the Commercial Code it would seem that a full-time Editor-in-Chief ${ }^{15}$ would need, on the legal side alone, the help of at least thirty of the most distinguished legal scholars in the fields being codified. Careful study might cause one to doubt if these legal standards have been met. ${ }^{10}$

There is a further major difficulty with the organization of this project. Since it is creating law to control complicated commercial transactions, mere collection of legal data and ex cathedra statements of rules of law as was the case in the Restatement, will not suffice. Because this Code is designed to control business activities, there should be among its intimate advisers impartial experts on commercial transactions comparable in numbers to the legal staff, to aid in constructing the provisions of the Code which ought to be supported by research data on the commercial transactions being created and regulated. So far as the writer knows there was no such advice and research except possibly in the preparation of the Bank Collections and Letters of Credit part of the Code. ${ }^{17}$

Of course there was copious advice from commercial pressure groups like the American Bankers Association. But this is always slanted in the interest of the group and is likely to do more harm than good. Hence the absolute necessity for impartial and expert commercial research which delves into the practices and needs of both sides of the commercial transactions. This requires a "grubbing for facts" far beyond knowledge of rules of law, records of decided cases, or the express desires of organized commercial interests. In absence of such careful economic research it

${ }^{10}$ These draftsmen and advisers are listed in the first part of each volume, for example, sce Restateament, Contracts ix (1932); Restatement, Trusts X (I935).

${ }^{11}$ Conflicts, Contracts, Torts.

${ }^{12}$ The work was begun in 1923 and the final volumes of these first three Restatements were published in 1934. See Restatements, supra notes 10 and $I I$.

${ }^{13}$ See 21 Commercial Laws of the Wordd 5.

14 24 Commercial Laws OF THE WORLD 6.

${ }^{10}$ During the time the Code was in process Professor Llewellyn taught a full-time schedule at both Columbia and Harvard Law Schools, was on the Executive Committee of the Association of American Law Schools as President-elect and President, and also carried on many other professional activities.

${ }^{20}$ Anybody desiring to make a comparative study of the respective careers of the framers and advisers of the Commercial Code and the Restatements may find them listed in the I949 draft stopra note 6 in the first comments to each Article, and in the Prefaces to the respective Restatements. The Directory of the Association of American Law Schools will give a summary of the careers of the draftsmen of the Restatements and the Code, almost all of whom are or have been law teachers.

${ }^{17}$ Uniform Commercial Code, Proposed Final Draft, Spring, I950, p. 6. 
is doubtful whether any commercial code could be more than an experimental shot in the dark.

Although these disturbing facts tend to raise a cloud of doubt, only an examination of the draft itself will indicate whether or not the editors have succeeded in producing an instrument worthy of the purpose.

\section{II}

\section{Choice of Language}

Since the Code is still in the tentative state, detailed and technical examination of specific language is not fruitful at this time, except that it may be helpful in correcting the numerous errors of draftsmanship and printing which are still legion throughout the draft, but which are being corrected by the diligent staff that is at hand to give attention at any time to the latest official copy. This discussion then will be confined to generalities of the plan and its execution with only enough reference to specific provisions to illustrate the points involved.

\section{A. Definitions}

Because codes are written embodiments of the law, choice of language is of paramount consideration. This draft is largely built upon technical words particularly defined, directly or by reference, in nine sections ${ }^{18}$ containing approximately one hundred and eighty separate, complete or partial definitions. Of these, forty-five are set out in Article I as general terms to be used throughout the Code. Subject to additional definitions and "unless the context otherwise requires,"19 they purport to be applicable to the entire Code. Forty-five more definitions are scattered over eight articles with the prefix "in this article unless the context otherwise requires." Approximately ninety other definitions with the introduction "other definitions applying to this article"21 and with no limiting phrases, are scattered throughout eight other articles. Thirty-seven of these ninety terms are repeated in at least two articles as "definitions in other articles applicable to this article."22 Nineteen are used in three or more articles and one, "check," is used in four or more.

These definitions would appear to be the skeleton of language upon which the Code is built; but it should be noted in passing that they are only a fraction of the terms which are subject to general or partial definitions throughout the Code, too numerous to catalogue here, and which fall within the catch-all phrases of Section I-20r: "Subject to additional definitions and unless the context otherwise requires."

Among the one hundred and eighty odd definitions are many terms ingeniously constructed to meet the technical needs of the legal relations being codified. There are also many definitions which change the dictionary or well-established legal

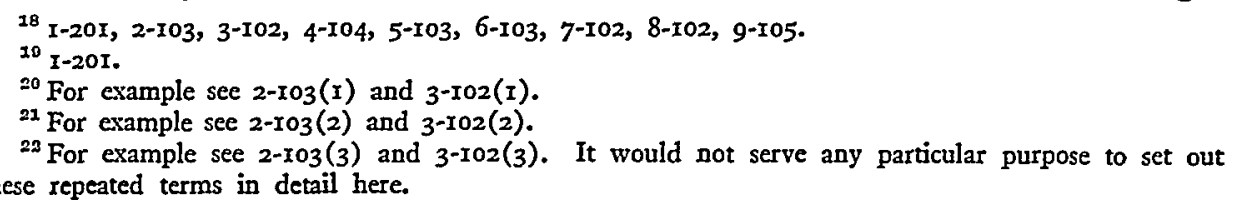


meaning of the terms either by giving them connotations totally or partially foreign to their established usage or by cutting out or adding to the context of the word much that changes its ordinarily understood meaning. For example merchant is defined in Section 2-ro4 as:

"Merchant" means a person who deals in goods of the kind or otherwise holds himself out as having knowledge or skill peculiar to the practices or goods involved in the transaction or to whom such knowledge or skill may be attributed by his employment of an agent or broker or other intermediary who by his occupation holds himself out as having such knowledge or skill. With respect to transactions of financing, payment, collection, and the like, a financing agency is a "merchant."

This word then becomes the basis of a sharp cleavage between legal rights of persons dealing in goods throughout Article 2 of the Code. ${ }^{23}$

An extreme example of the extent to which the draftsmen have twisted the wellestablished meaning of words may be found in the definition of two terms: Local Bank and Metropolitan Bank. ${ }^{24}$

"Indirect remittance" is the use by a bank without foreign correspondents of the foreign credit facilities of another bank. In indirect remittance transactions the bank dealing with the original customer is the "local bank" and the bank whose credit facilities are used is the "metropolitan bank." Unless otherwise agreed, a local bank is a customer of a metropolitan bank.

These are not isolated examples of unusual slips in draftsmanship. At least one hundred ${ }^{25}$ out of the one hundred and eighty defined terms partake, wholly or

${ }^{23}$ Among others see 2-209(2), 2-314(I), 2-603, 2-605(I)(b), 2-609(2).

24 $6-\operatorname{rog}(1)$.

25 The words with unusual meanings and the sections in which they occur are set out below. The words in quotes are from the text of the Code; those in parenthesis, their approximate defined meanings.

Sec. $T-201$

( 2) "Aggrieved party" (?).

(3) and (10) Distinction between Agreement and Contract (contract rights and obligations).

(4) "Bank" (Banker).

(5) "Bearer" (Possessor).

( 9) "Conspicuous" (?).

(II) "Creditor" (Creditor and Fiduciary).

(16) "Fungible" (Equivalent Units).

(19) "Holder" (Possessor of Negotiable Paper); cf. 3-302(r).

(2I) "Insolvency proceedings" (Liquidation Proceedings).

(23) "Money" (Legal Exchange).

(24) "Notice" (constructive notice).

(26) "Notifies" (Reasonable steps toward Notice).

(27) "Organization" (Legal or commercial entity).

(28) "Party" (Contractor).

(30) "Presumption" (Rebuttable Presumption).

(3I) "Purchase" (Transfer of interest).

(32) "Purchaser" (Transferee of interest).

(33) "Remedy" (Remedial right).

(35) "Rights" ("Includes remedies").

(37) "Send" (?).

(38) "Signed" (Authentication).

(39) "Surety" ("includes guarantor").

(40) "Telegram" (?). 
(4I) "Term" (?).

(44) "Wares of commerce" (Goods delivered to bailee).

(45) "Written" ("reduction to tangible form").

Sec. $2-103$

(2) "Banker's credit" ("Irrevocable credit" etc.); cf. Financing agency, 2-325, 2-104.

"Between merchants," see "Merchants" 2-104(I).

"Buyer in ordinary course of business" (?l?). 2-403.

"Cancellation" (Termination for breach). 2-106(4).

"Confirmed credit," of. 2-325 comment 3.

"Contract for sale" (contract to sell and sale [passage of title]), 2-Io6.

"Cover" (Mitigate damages). 2-7I2.

"Installment contract" (contract for both delivery and payment in installments). 2-6r2.

"Letter of credit" (Irrevocable credit). 2-325.

"Lot" (parcel or single article). 2-ro5.

"Merchant" (dealer, expert or purported expert). 2-I04.

"Overseas" (Air or water shipment etc.); cf. 2-323.

"Person in Position of a Seller"; of. 2-707.

"Sale" ("Passing of title" etc.); of. Sales Act Sec. I.

"Termination"; cf. "Cancellation" 2-106.

Sec. 3-102

"Banking day" (Day on which every department is open).

"Issue," of. N. I. L. Igr.

"Secondary party," of. N. I. L. I92.

"Acceptance" (Must be on the draft).

"Accommodation party" (Surety), see I-20I(39).

"Alteration" (material alteration), quaere if a definition at all.

"Certificates of Deposit" (Negotiable certificates of deposit).

"Definite time" (Definite time subject to contingencies); of. 3-rog.

"Dishonor," cf. 3-507, 4-404.

"Draft," cf. 3-I04, 3-102(r)(d).

"Holder in due course," 3-302, I-201 (19).

"Instrument" (Negotiable instrument)? probably not a definition.

"Negotiation," cf. 3-202, I-20I(I9), circuitous.

"Note" (simple negotiable note), see 3-IO4(2) \& (3).

"Notice of Dishonor," see 3-508, Not a definition; but see I-20I(24).

Sec. 4-104

"Account" (Bank account).

"Customer" (One having bank account etc.).

"Item" (Instrument for payment of money).

"Properly payable" (?).

"Settle" (to make one of three kinds of payment).

"Collecting bank" (collecting bank not payor).

"Depository bank" (collecting bank).

"Value" (Parting with something) 3-303; cf. N. I. L. 25, 19r.

Sec. 5-103

"Customer" (Buyer of credit).

"Draft" (request for payment); cf. 3-ro2.

"For account of" (receiver of credit or payment).

"Beneficiary" (person entitled to draw).

"Credit" (letter of credit).

"Good faith purchaser" (Holder in due course with knowledge of letter of credit), cf. 3-302, I-20I(I9), 5-I05, 7-502(I).

"Issuer" (bank issuing letter of credit).

Sec. 6-103

"Remittance" ("procurement of payment").

"Customer" (remitter).

"Indirect remittance" (foreign remittance, etc.), 6-rog.

"Local bank," 6-Iog.

"Metropolitan bank" (a bank whose foreign credit facilities are used by another bank which has none) 6-rog. 
in part, of this eerie unreality of meaning. It should be further noted that these definitions within themselves involve the use of many terms which have been given special meaning in other definitions. (The words in italics in the definitions and sections quoted throughout the rest of the body of this article are such defined terms.) The result is a compounding of definitions to create a wonderland of exotic words which may be a delight to the lovers of intricate semantics, but which will rise to plague any lawyer, businessman, or judge who attempts to apply such a statute to the regulation of everyday transactions. This extensive use of definitions should be contrasted with the European codes, both commercial and civil, which are constructed on the current legal language of the time with practically no artificial definitions, ${ }^{26}$ thus assuring continuity of the law in codified form.

\section{B. New Language}

There is a further difficulty with the language of the Code. In addition to the defined words, the draftsmen have seen fit to use a lot of new words to express old concepts. Where the language is defined there is the mere struggle with definitions, but new phraseology also raises the question of why the new language (not defined) is used. The Commissioner's notes to the various sections edited in the

Sec. 7-102

"Bailee" (Person issuing document of title).

"Consignee" (consignee named in bill).

"Consignor" (consignor named in bill).

"Issuer" (Bailee with variations and additions).

"Value" (consideration).

"Duly negotiated" (negotiation in regular course of business to Holder in Due Course), 7-50r.

Sec. 8-102

"Issuer" (Includes surety, holding companies or persons controlling principal debtor, trustees, receivers or like), 8-20I.

"Restrictive indorsement" (Indorsement to create agency), 8-308(3).

"Subsequent purchaser" (Includes finder, thief, converter, etc.), 8-302.

"Valid" (among others, "does not mean the security is free from forgery"), 8-103.

"Value" (among others "delivery pursuant to a pre-existing contract for sale").

Sec. $9-\operatorname{ros}(r)$

"Account debtor" (Includes debtor on "chattel paper" or contractsl) but "Account," see 9-106, excludes rights "evidenced by" . . . "chattel paper."

"Debtor" ("Person whose property is subject to a security interest," real surety).

"Instrument" (excludes chattel paper).

"Secured lender" (Holder of security interest, loans and otherwise).

Sec. $9-\log (2)$

"Account" (debt for goods or services evidenced by instrument or chattel paper or judgment).

"Consumers goods" ("Goods used for the debtor's personal family or household purposes").

"Contract right" ("right to payment not yet earned by performance" except wages, salary, judgment or right on instrument).

"Crops" (farm or forest products except lumber or timber).

"Crops," "Equipment," "Farm products," "Inventory," (You look at g-rog and then tell me).

"Lien Creditor" (?), 9-303(3) (creditors holding ordinary liens omitted).

"Possession of lender" (Includes possession on behalf of lender except by debtor).

"Proceeds" (Includes "earned" accounts).

${ }^{26}$ In this respect contrast Louisiana's civil code, Book III, Title VII (Dainow I947) (taken from French Civil Code) pp. 448ff. and German Civil Code, Seventh Section (Chang Hai Wang's Trans. (1907)) pp. 95ff., with Article 2 of the proposed Commercial Code; Compare also German Cheque Law, 25 ComMERCIAI LAWS OF THE WORLD, 48rff., with Article 3. 
Comments usually cite the familiar provisions of the uniform laws with the explanation "rephrased" or the like. The lawyers and courts are left with the task of determining to what extent the new language is meant to create new legal relations not found in the older acts.

One example will suffice to illustrate this ever present difficulty. Section 8-30I in defining the rights of a "bona fide purchaser" (holder in due course) of a security uses the following language:

A bona fide purchaser in addition to acquiring the rights of a purchaser acquires also a perfect title to the security.

By interpreting the terms in italics which are defined elsewhere ${ }^{27}$ and by consulting the Comment ${ }^{28}$ we reach the conclusion that a "bona fide purchaser" with the rights of a purchaser, ${ }^{20}$ takes as an assignee of his transferor; in addition, as a "bona fide purchaser" by definition ${ }^{30}$ probably includes the rights of a "purchaser" for value"32 and a "subsequent purchaser"33 for value, he cuts off some of the defenses of the "issuer" Comment) ${ }^{36}$ cuts off prior property rights in the paper. In other words he gets additional rights about the same as a holder in due course. Two questions remain

${ }^{27} 8-302,8-301(2), 8-102(b)$.

${ }^{28}$ Comment to 8-30I, p. 666 .

20 8-30r(2) provides: "Upon delivery of a security the purchaser acquires the rights in the security which his transferor had or had actual authority to convey but a person who himself participated in any fraud or illegality cannot by later purchase increase his original rights if at the time of such participation he knew of the fraud or illegality."

${ }^{30} 8-302$ (2) provides: "A 'bona fide purchaser' is a purchaser who in good faith, for value and without notice of any claims of ownership takes delivery of a security in bearer form or of one in registered form issued to him or indorsed to him or in blank."

${ }^{31}$ I-20I (32) provides: "Purchaser' means a person who takes by purchase"; and I-20I(32) " 'Purchase' includes taking by sale, mortgage, pledge, lien, issue or re-issue, gift or any other transaction creating an interest in property."

32 8-303 provides: "Value' with respect to purchase for value means

(a) any consideration sufficient to support a simple contract including the extension of immediately available credit whether or not drawn upon and whether or not a charge-back is provided for in the event of difficulties in collection; or

(b) taking a security as collateral for a pre-existing claim; or

(c) delivery pursuant to a pre-existing contract for sale."

${ }^{33}$ 8-302(r) provides: "A 'subsequent purchaser' is a person who takes other than by original issue."

34 8-202(2) (3) and (4) provides: "(a) A security other than one issued by a government or governmental subdivision or agency even though issued with a defect going to its validity or proper form is valid in the hands of a purchaser for value and without notice of that defect unless the defect involves a violation of constitutional provisions in which case it is valid only in the hands of a subsequent purchaser for value and without notice of the defect.

"(b) The rule of subsection (a) applies to an issuer which is a government, governmental subdivision or agency only if there has been substantial compliance with the legal requirements governing the issue or if the issuer has received substantial consideration for the issue as a whole or for the particular security and a stated purpose of the issue is one for which the issuer has power to borrow money.

"(3) Except as otherwise provided in the case of forged or unauthorized signature on issue (Section 8-205), unless otherwise agreed lack of genuineness of a security is a complete defense even against a purchaser for value and without notice.

"(4) All other defenses of the issuer including nondelivery and conditional delivery of the security are ineffective against a purchaser for value who has taken without notice of the particular defense."

${ }^{35}$ See 8-20I.

${ }^{30}$ 8-301, Comment. 
unanswered. Section 57 of the N. I. L. which the Comment cites defines these rights as follows:

[He] holds the instrument free from any defect of title of prior parties and free from defences available to prior parties among themselves, and may enforce payment of the instrument for the full amount thereof against all parties liable thereon. (Underlining added.)

Now, first, it becomes immediately evident that both the Code and the Comment omit reference to defenses of indorsers and transferors. ${ }^{37}$ Does this mean that these defenses are not cut off? It might be answered that these rights are included in "perfect title" even though title normally refers to property rights rather than to choses in action, and it is so used in the Comment. ${ }^{38}$ Perhaps such defenses are cut off; but regardless of your answer to this there is a second question. "Perfect title" usually means title against the whole world. Note that N. I. L. Section 57 cuts off rights of prior parties only. Does this mean that the "bona fide purchaser" under the Code, if he be a trustee, agent, factor, receiver, or other fiduciary, has perfect title against his beneficiary? This is a startling result but clearly within the wording and the legislative history, else why use the new terminology? If it be answered that the "bona fide purchase" requires him to take "without notice of any claims of ownership"39 including those of his own beneficiaries, then you get the equally startling result that no fiduciary and the like can have the rights of a "bona fide purchaser" (holder in due course). Either result is made possible and probable under this use of new words. It might be answered, "Anybody knows that is not the law." To resort to that kind of interpretation, it must be assumed that there is a complete and available "common" law in all jurisdictions outside of the Code. Unfortunately no such uniform common law (outside of the statutes to be replaced) exists. Only if it did could draftsmanship of this kind be justified, and if that were the state of the law, there would be little need for the Code.

This is not an unusual case to be found only after long research. The identical error of using "perfect title" or its equivalent to change the present clearer phraseology of uniform laws, is repeated three times ${ }^{40}$ in other parts of the Code. New language appearing throughout the entire $\mathrm{draft}^{41}$ will necessarily be subjected to some sort of historical interpretation. In fact how else do you explain its use?

This novel wording so popular with the draftsmen causes new problems to grow where none existed before, which, for their solution, require a naive postulation of an omnipotent "common" law such as only broods over law schools.

\footnotetext{
${ }^{37}$ But they have liabilities, see 8-306, and therefore probably have defenses.

${ }^{38} 8-301$, Comment 1 .

${ }^{39} 8-302(2)$ supra, note 30 .

${ }^{10} 7-502$ (I) (a) and (b), and cf. 3-305(x), "free from ( $\mathrm{x}$ ) all claims on the part of any person."

"The expressions "rephrased," "completely rephrased," and the like in reference to present Uniform Laws appear fifty-four times in Comments to Article 2, Sales, alone.
} 


\section{UNITY OF THE CODE}

\section{A. The Same Word With Multiple Meanings or Definitions}

Not only are words and definitions throughout the Code used in unnatural or new meanings, but also it is quite common to find the same word given different connotations in various parts of the Code.

Some of the most glaring of these shifts of meaning are:

Value. Although the present uniform laws drafted at different times by various people get along with almost identical definitions of value, ${ }^{42}$ this Code contains four substantially different definitions of the term. Articles 3 and 4 use a concept of performed contracts, with a slight variation in Article 4..$^{3}$ Article 7 adopts contracts, checking credit, and security for pre-existing claims; ${ }^{44}$ Article 8, consideration, any extension of credit, security for pre-existing claims, and delivery of goods pursuant to contracts; $;^{45}$ Article 9, satisfaction or security for pre-existing claims or consideration; ${ }^{46}$ and, in addition, it creates another concept, "new value," borrowed with alterations from the Uniform Trust Receipts Act. ${ }^{48}$

42 The following sections of Uniform Laws are on value: Conditional Sales Act $q 6(x)$, Bills of Lading Act 53, Stock Transfer Act 22, Warehouse Receipts Act 58; and cf. Negotiable Instruments Law 25, 27, and $19 \mathrm{r}$.

3-303 provides: "A holder takes for value:

"(a) to the extent that the agreed consideration has been performed or that he acquires a security interest in or a lien on the instrument otherwise than by legal process; or

"(b) when he takes the instrument in payment of or as security for an antecedent claim against any person whether or not the claim is due; or

"(c) when he gives a negotiable instrument for it or makes an irrevocable commitment to a third person."

Cf. 4-ro4(3)(m): "Value.' Section 3-303." But cf. 4-212:

"When Bank Is Holder in Due Course.

For purposes of determining its status as a holder in due course, the bank has given value to the extent that it has a security interest in an item and a bank which takes a negotiable instrument before maturity for deposit in a checking account in good faith and without notice of any claim or defense is a holder in due course to the extent that credit given for the instrument is withdrawn or applied, whether before or after maturity, before the bank has had a reasonable opportunity, after having received notice of a claim or defense, to charge back the amount of the interest purchased or credit given."

" 7-102(x) (g) provides: "Value' with respect to purchase for value means

(i) any consideration sufficient to support a simple contract; or

(ii) the extension of immediately available checking credit whether or not drawn upon and whether or not a charge-back is provided for in the event of difficulties in collection; or

(iii) taking goods or documents of title in satisfaction of or as security for a preexisting claim."

45 8-303 provides: "Value' with respect to purchase for value means

(a) any consideration sufficient to support a simple contract including the extension of immediately available credit whether or not drawn upon and whether or not a charge-back is provided for in the event of difficulties in collection; or

(b) taking a security as collateral for a preexisting claim; or

(c) delivery pursuant to a pre-existing contract for sale."

${ }^{40} 9-108$ (I) provides: "A person gives 'value' for rights in property if he takes his rights

(a) in satisfaction of or as security for a preexisting claim; or

(b) in return for any consideration sufficient to support a simple contract."

47-108(2) provides: "Where a secured lender makes an advance, incurs an obligation or otherwise gives new value which is to be secured by after-acquired property his security interest in the after-acquired collateral is not security for a pre-existing debt or claim if the debtor acquires his rights in such collateral either in the ordinary course of his business or under contract of purchase made within a reasonable time after the making of the security agreement and pursuant thereto."

${ }^{48}$ P. 728, Comment 2. 
Among other things this gets the fantastic result that a bank taking, for credit to a depositor's account, a draft with a negotiable document attached can, in this ordinary commercial situation, be a holder for value of the document but not of the draft. ${ }^{49}$

Customer has at least four different meanings. In Articles 3 and 4 it is a person having a bank account; ${ }^{50}$ in Article 5 a buyer of a credit; ${ }^{51}$ in Article 6 a remitter and a "local bank." In none of these articles is the term used in its most common commercial meaning.

Letter of Credit. Although Article 5 is devoted to letters of credit and defines and explains them at some length, which meaning is adopted in Article $3{ }^{63}$ in Article 2 the term means "irrevocable credit" etc. ${ }^{54}$

Account has at least ${ }^{55}$ three defined meanings. In Articles 3, 4, and 6 it means bank account; ${ }^{56}$ in Article 9 it has contradictory definitions. In 9-105(a),

"Account Debtor" means the person who is indebted on account, chattel paper, or contract right,

while in 9-106 it means

a right to payment for goods sold or leased or for services rendered which is not evidenced by chattel paper. 57

Even casual readings of the Code will disclose many more cases where words are used in multiple meanings. ${ }^{58}$

\section{B. Same Concept With Different Words}

Another example of lack of coherence is the fact that the same or similar concepts are expressed in entirely different language in various articles of the Code. Two glaring instances of this annoying style will suffice.

The good faith purchaser for value of negotiable paper who cuts off defenses and gets better title than his vendor, appears in all sorts of guises. Although there

${ }^{\circ}$ Cf. $3-303,7-102(\mathrm{I})(\mathrm{g})$. Cf. 4-2II, 4-2I2, 4-I04(I)(e): "IItem' means any instrument for the payment of money. ..."

${ }^{50} 3-\mathrm{IO}_{2}(3), 4-\mathrm{IO}_{4}(\mathrm{I})$ (d): "CCustomer' means any person having an account with a bank or for whom a bank has agreed to collect items and includes a bank carrying an account with another bank."

${ }^{61} 5-103$ (I) (a): "A 'customer' is a buyer or other person who causes a bank to issue a credit."

${ }^{52} 6-\mathrm{IO}_{3}(\mathrm{r})(\mathrm{b}):$ " $\mathrm{A}$ 'customer' is the person who initiates the remittance and includes a purchaser of a bank's draft drawn to order of the remittee." Cf. 6-rog(r): "Unless otherwise agreed, a local bank is a customer of a metropolitan bank."

${ }^{53} 3-\mathrm{IO} 2(3)$. See definition of credit, 5-104, too long to repeat here.

54 2-I03 (2), 2-325(3): "Unless otherwise agreed the term 'letter of credit' or 'banker's credit' in a contract for sale means an irrevocable credit available by its terms not only to the seller but also to a good faith purchaser of drafts drawn under it which is issued by a financing agency of good repute and, where the shipment is overseas, of good international repute. . . ."

${ }^{56}$ For use in another sense, see 3-206 and 6-II2.

${ }^{60} 3-\mathrm{IO} 2(3), 6-\mathrm{IO}_{3}(3), 4-\mathrm{IO} 4(\mathrm{I})(\mathrm{a})$ : "Account' means any account with a bank and includes a checking, time, interest or savings account."

${ }^{57}$ Of course it is intellectually possible to distinguish between account as used in "Account Debtor" and in "Account"; but what is the practical value of this type of intellectual gymnastics when there are plenty of other words available to express the ideas?

${ }^{68} \mathrm{~A}$ few of these are: "Money" I-20r(23), 3-107; "Issuer" 3-ro2(r) (c), 5-104, 7-ro2(r)(f), 8-201 "Draft" 3-IO2(I)(d), 3-I04, 5-I03; "Goods" 2-r05, 2-ro7, 9-105, 9-109; "Buyer in ordinary course of business" 2-403, 3-302 (see Comment 3), 9-307, cf. 7-501 (4). 
has been some effort to unify the concept in the definition of "holder,"59 it ends there. In Articles 3 and 4 he is a "holder in due course"; 60 in Article 5 he is a "good faith purchaser", 81 in Article 7, "a holder to whom negotiable document of title has been duly negotiated."02 Article 8 calls him a "bona fide purchaser"; 63 and in Article $g$ he has all three of the above meanings ${ }^{64}$ plus the designation "assignee who takes his assignment for value, in good faith and without notice of a claim or a defense except as to defenses of the type which may be asserted against a holder in due course of a negotiabie instrument under the article on Commercial Paper," ${ }^{305}$ and he also has a near kin, "Purchaser for value of chattel paper."66

Now it may be that these terms are intended to signify technical differences in substantive rights available to the parties designated; but, if they do, such differences are not clearly set out. As a matter of fact these concepts are so much alike that all but the last could be codified under the term "holder in due course."

A second example of a failure to use general terminology is found in the manner in which the Code deals with the concept of warranty. Although this subject is currently covered by at least five uniform laws ${ }^{87}$ and the Contracts Restatement, ${ }^{68}$ all agree that a transferor of commercial paper whether negotiable or not is subject to at least four basic warranties: (I) the paper is genuine; (2) the transferor has title or right to transfer; (3) he has no knowledge of disabling facts; and (4) the obligation is valid. ${ }^{69}$ As is to be expected there is a variation of wording in the statutes but in many the terminology is almost identical. Unity here would therefore seem to be indicated, and appears to be possible to accomplish, with variations necessary only to cover special instances. But what has the Code done? Articles 3 and 4 though couched in almost identical language set out seven warranties; ${ }^{70}$ Article 7 covers three, ${ }^{71}$ and Article 8 the same three but in quite different verbiage ${ }^{72}$ and with some additions as to broker's warranties. ${ }^{73}$ Now due to different verbiage, it is doubtful if the warranties set out are coexistent even when the different types of paper appear in the same transaction; but what is worse, the remaining six articles (except Sales, Article 2) though they all cover situations where transfers of commercial paper and contracts are involved, seem to be silent on this basic subject. The Sales Article sections on warranties ${ }^{74}$ are couched in language which seems to have no relation to the subject elsewhere in the Code.

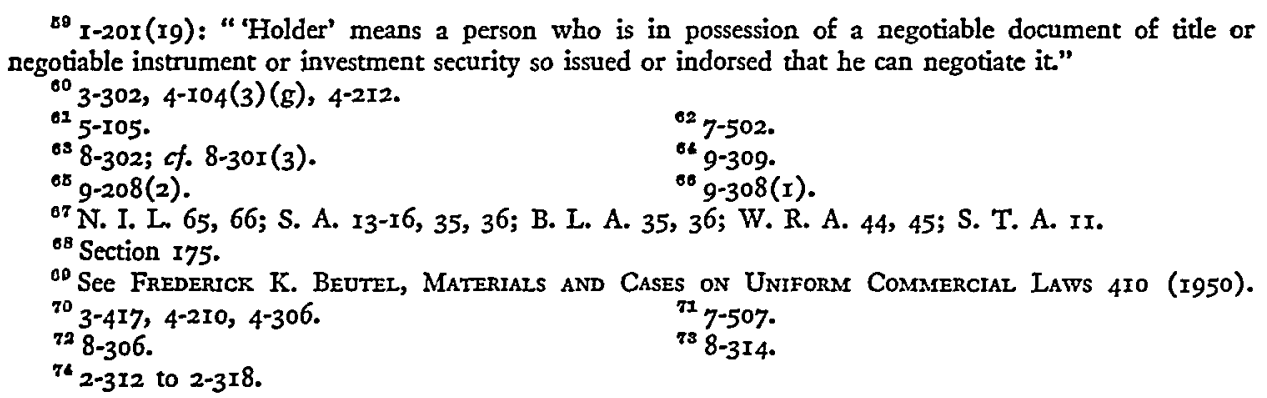


The Code then is less unified on this basic subject than are the current uniform laws and the Contracts Restatement, and covers much less of the subject matter than the current statutes and Restatement.

Similar absences of unity in basic concepts of commercial law are evident throughout various articles of the Code.

\section{III}

\section{A Sample Problem}

What has been said so far is mostly theory; and, perhaps, can be answered simply by the proposition that if the Code offers workable regulation of ordinary business transactions, difficulties of language are incidental and will be overcome as the profession becomes used to the new expressions. It would be wise, therefore, to pause long enough to apply the Code to a sample commercial case as a test of its usefulness. Such a problem, which arises every day, might be the following. A local dealer buys from a farmer a heavy wagon and two fine draft horses for which he gives him a note, otherwise negotiable in form, for $\$ 300.00$ with a clause, "This note is given for a team of horses and a wagon, title remaining in the seller until paid." "75 The farmer discounts the note for credit to his account with his local banker. The dealer then sells the horses and wagon to a second farmer who borrows the money on a chattel mortgage from bank number two. At maturity the dealer defaults, claiming fraud. The discounting banker asks for his rights under the Uniform Commercial Code. The Code purports to codify the law both as to notes and security.

\section{(I) As to the note:}

The note is not a "note" within the meaning of Section 3-ro4(3) because it "purports to create or reserve security" so we turn to the Security Article, 9. It provides ${ }^{76}$ "nothing in this article limits the rights of a holder in due course of a negotiable instrument"; but this is not a "negotiable instrument." It is chattel paper within the definition of Section 9-Io5(I)(b). ${ }^{77}$

Section 9-308 provides, "a purchaser for value of chattel paper who obtains delivery thereof has a right to such paper and its proceeds in priority to the rights of an earlier secured lender," etc. Of course there is no "earlier secured lender" but this appears to be the closest section. So the bank has some right in "proceeds" but nothing is said about the rights on the note against the maker or indorser. The N. I. L. covers this but the N. I. L. would be repealed by the Commercial Code. ${ }^{78}$

\footnotetext{
${ }^{75}$ If the reader desires he can add a chattel mortgage, conditional sale, or other evidence of title retention without further complicating the problem. 9-I05(x)(b), infra note 77.

${ }^{76}$ 9-309.

77 9-105(x)(b): “'Chattel paper' means a writing of a type whose transfer in ordinary course of business requires delivery and which evidences a security interest in or lease of goods. If the writing is of a type whose transfer in ordinary course of business does not customarily require delivery, the right is an account or contract right. Where an instrument is secured by chattel paper both writings together constitute the chattel paper relating to the transaction. . . ."

${ }^{78}$ II-I02.
} 
So the attorney is remitted to the decisions. The recent decisions are not helpful because for twenty-five to fifty years the subject has been controlled by the N. I. L., and, before that time, the law was in complete confusion on such matters as negotiability and liability of indorsers of chattel paper. This omission is the more surprising because chattel notes have been a cause celebre ever since the N. I. L. was first drafted. ${ }^{79}$

If by any chance this analysis is wrong and the note is, or could be made, negotiable within Article 3, then the bank, having given credit, is not a holder for value, and therefore not a holder in due course, under the provisions of Section 3-303, which throws us back on the old common law first-in-first-out doctrine, with its maze of nonsensically impractical bookkeeping problems. But due to the fact that value in Article 9, Section 9-108, is "Any consideration sufficient to support a simple contract," the discounting bank although not a holder for value of the note, by the same operation is a "purchaser for value" of the "chattel paper"; so it may be that the bank has some "rights" in the horses and wagon under the Commercial Code. (2) As to the security:

The horses and wagon are clearly "collateral" under the definition of Section $9-105^{80}$ and the discounting bank may have a "purchase money security interest"; 81 but if it does it is as transferee of the farmer-vendor. What then were the farmervendor's rights? Section 9-20r provides:

Except as otherwise provided by law a security agreement is effective according to its terms between the parties and against any purchaser from or creditor of the debtor.

So, unless the law provides otherwise, the security agreement is good against the purchasing farmer in the hands of the farmer-vendor.

The Code provides, Section 9-3I0, that the purchaser of collateral takes subject to perfected security interests, and Section 9-302 provides what interests must. be protected by filing a financing statement (which apparently did not occur here).

A financing statement must be filed to perfect all security interests except the following: .... (c) a purchase money security interest in farm equipment having a purchase price not in excess of $\$ 2,500$. . .

But Section 9-307 provides:

In the case of inventory, a buyer in ordinary course of business takes free of a security interest even though perfected....

${ }^{70}$ See Brannan, Negotiable Instruments Law 42I, 437, 476 (3d ed. 1919), reproducing the AmesBrewster controversy on this point.

${ }^{80} 9-\operatorname{ro5}(\mathrm{r})(\mathrm{c})$ : " 'Collateral' means the property subject to a security interest . .."

81 9-107: "A security interest is a 'purchase money security interest' to the extent that it is

(a) taken or retained by the seller of the collateral to secure all or part of its price; or

(b) taken by a person who by making advances or incurring an obligation gives value to enable the debtor to acquire rights in collateral if such value is in fact so used; or

(c) taken by a person who for the purpose of enabling the debtor to pay for or acquire rights in collateral makes advances or incurs an obligation not more than ten days before or after the debtor receives the collateral even though the value given is not in fact used to pay the price." 
It appears then that if the horses and wagon are "farm products" the financing agreement must be registered to perfect the security interest. If they are "equipment" such registration is not necessary and if they are "inventory" the security is cut off regardless of registration, by a "buyer in ordinary course of business."

Section 9-rog(5) provides "inventory does not include farm products or equipment." This phrase makes the terms mutually exclusive but creates a dangling disjunctive (characteristic of much of the draftsmanship of this Code) which would seem to leave the term "equipment" subject to about five meanings; ${ }^{82}$ but fortunately all of these terms are defined in Section 9-rog as follows:

Goods are ... (3) "equipment" if they are used primarily in business (including farming or a profession) or by a debtor who is a non-profit organization or a governmental subdivision or agency or if the goods are not included in the definitions of inventory, farm products or consumer goods. Equipment does not include goods which at the time a security interest attaches are being held or prepared for sale or to be furnished under a contract of service;

(4) "farm products" if they are crops, livestock and products of crops or livestock in their unmanufactured state, such as ginned cotton, wool-clip, maple syrup, milk and eggs and if they remain in the possession of a debtor from whose raising, fattening, grazing or other farming operations they derive;

(5) "inventory" if they are held or are being prepared for sale or to be furnished under a contract of service or if they are raw materials, work in process or materials used or consumed in a business. Inventory does not include farm products or equipment. . . .

After a careful and prayerful examination of these definitions one might venture the opinion that the wagon at the time of the first sale was "equipment." The horses at this time would be "farm products" except for the fact that they do not "remain in the possession of a debtor from whose ... farming operations they derive." At that time they were not "inventory" because they were not "being held or.prepared for sale" so they must have been "livestock."

Just what is the significance of this designation is not apparent but it seems that so far as the wagon is concerned, being equipment and by value under $\$ 2,500.00$, filing is not necessary to perfect the security interest; but "livestock" is not included in the exception to the requirements of filing ${ }^{83}$ in Section 9-302 so the vendor-farmer

${ }^{82}(x)$ Farm products or farm equipment, (2) or any kind of equipment (3) or farm cqiupment if found on farms (4) or farm equipment whether on farms or not, or (5) any kind of equipment found on farms.

${ }^{83}$ It is not apparent just where one would file to protect "livestock" defined in 9-rog(6), under Section $9-40 \mathrm{I}(\mathrm{I})$ which reads as follows:

"( $I$ ) If filing is required by this Article (Section 9-302) in order to perfect a security interest, a financing statement must be filed

(a) when the collateral is accounts, chattel paper, contract rights, inventory or equipment other than equipment used in farming operations, then in the office of the Secretary of State [and in addition if all of the debtor's places of business are in a single county, in the office of the ... in that county]; and

(b) when the collateral is consumer goods, equipment used in farming operations or farm products, then in the office of the ... in the county of the debtor's residence but if the debtor is not a resident of this state then in the office of the ... in the county where the goods are located after the security interest has attached, and in addition when the collateral is growing crops in the office of the ... in the county where the land on which the crops are growing is located." 
has not perfected his security interest in the horses. Since the security interest, not perfected, is cut off by subsequent purchasers without knowledge, ${ }^{84}$ if the purchasing farmer had no knowledge of the security interest in the horses, it is gone. However this is not the end; when the horses and wagon came into the hands of the dealer they were clearly "inventory" within the definition of Section 9-rog(d) above. Now Section 9-307(I) provides:

In the case of inventory, a buyer in ordinary course of business takes free of a security interest even though perfected and even though the buyer knows of the terms of the security agreement.

A "buyer in ordinary course of business" is not defined in the current draft of Article 9 nor listed with the approved definitions but the farmer-purchaser seems to be such a buyer. ${ }^{85}$ So the farmer-purchaser cuts off all the rights of the farmervendor in the "collateral," "equipment," "livestock," and "inventory," i.e., the horses and wagon.

Now, does the discounting bank get any greater rights in the "collateral" than the farmer-vendor? Sections 9-308 and 9-208, the only ones on the subject, say nothing about the point so the bank, under Section 9-3I9 is probably only a common law assignee of non-negotiable paper with rights no greater than its assignor. But if the counsel can prove that at "law merchant" in the state involved the note was "negotiable," then perhaps Section 9-309 ("Nothing in this Article limits the rights of a holder in due course of a negotiable instrument (Section 3-302) . ..") may be used by analogy, as provided in Section I-I02(I) and (3). ${ }^{\mathbf{8 6}}$

Now if you still follow me (I am not sure I do) the discounting bank by law merchant may be a holder in due course of the.note; and as such, by ancient common law, is a holder in due course of the perfected security, ${ }^{87}$ i.e., the wagon, and may take it or the "proceeds" if the rights of the farmer-purchaser or the second financing bank have not intervened. (You may try your hand at working out the "proceeds" and the rights of the second bank. I am exhausted.)

After intricate study it appears that the discounting bank has no rights directly given by the Code against (I) the farmer-vendor; (2) the debtor (except for "proceeds"); (3) the horses or wagon; (4) the farmer-purchaser; or (5) the financing bank.

86 9-30I (I)(d): "An unperfected security interest is subordinate to the rights . . of a buyer even though not a buyer in ordinary course of business to the extent that he receives delivery of the collateral before he receives knowledge of the security interest and before it is perfected."

${ }^{85}$ The Sales Article, 2-403(4), partially defines him as follows:

"'Buyer in ordinary course of business' includes a person to whom goods are shipped pursuant to a pre-existing contract or one to whom they are delivered on credit, but does not include a pawnbroker or a person taking from one not dealing in goods of that kind or a person taking an interest in inventory in bulk or as security or a person taking at an hour or under other circumstances which negate good faith or a person purchasing from a farmer."

${ }^{86} \mathrm{I}$-rO2(I) \& (3): "(I) This Act is remedial and shall be liberally construed and applied to promote its underlying reasons, purposes and policies. ..." "(3) A provision of this Act which is stated to be applicable 'between merchants' or otherwise to be of limited application need not be so limited when the circumstances and underlying reasons justify extending its application."

${ }^{87}$ Demainbray v. Metcalfe, 2 Vern. 698, 23 Eng. Rep. 1052 (Ch. 1715). 
All else must be determined by the "law merchant" or "common law" which has been more or less confused or dormant for the last fifty years.

A "Code" that so ingeniously sidesteps simple problems of law which it should solve can only be a bonanza to an already overworked legal profession and a burden on commerce.

\section{IV \\ Scope and Coverage}

As the readers will begin to suspect from the foregoing, the Commercial Code is not a code at all in the sense in which the term is commonly used to indicate the reductions of general concepts of law to written statutes. The style of the various sections is more like the Restatement which was designed as a detailed statement of holdings of cases rather than a scientific exposition of legal principles. The sections are often limited to narrow statements of facts in a style using long and complicated sentences full of exceptions within exceptions and conditions upon conditions. ${ }^{88}$ Such particular statements, as indicated by the problem above, leave vast areas of the law uncovered; and reduce the "Code" to a mere collection of statutes. The scope of these individual statutes may be roughly classified as follows.

Article 2, Sales, according to the Comment, is a revision of the Uniform Sales Act in different language, and with some additions. Sixty per cent of the sections in this article seem to contain much the same legal concepts as, but a rewording of, the original Sales Act, with no important substantive changes except that the sales provisions on documents of title are moved to Article 7. The new sections are largely devoted to details of court procedure, definitions, and narrow rules covering specific situations. Whether this is a better or worse codification than the Sales Act would require a detailed examination far beyond the scope of this article. Such studies as have been made do not seem to be complimentary. ${ }^{89}$

Article 3, which replaces the N. I. L., a general statute covering all negotiable instruments payable in money and the rights and duties of the parties thereto, is a narrow statute involving only checks, drafts, some promissory notes, and certificates of deposit." In no place in the "Code" are there to be found any general sections on various types of negotiable paper, all of which are treated pretty much alike in current business practice. For the negotiability of bonds, chattel paper, investment trust certificates, and all other types of commercial paper, and the rights of parties thereto, one must look elsewhere. Some of this is picked up in other articles but much is left dangling in a fashion which is certain to be a source of confusion

\footnotetext{
${ }^{88}$ For example see I-I05, 2-201, 2-401, 2-503, 2-706, 3-304, 3-307, 4-208, 4-301, 4-311, 5-1 18, 5-125, $7-403,7-409,8-402$, and almost any section in Article 9 .

${ }^{80}$ See Williston, The Law of Sales in the Proposed Uniform Commercial Code, 63 Harv. L. Rev. 56 I (1950); Rabel, Sales in the Proposed Commercial Code, I7 U. of Chr. L. Rivv. 427 (1950).

${ }^{90}$ 3-104.
} 
and a drawback to the enactment of the "Code." A detailed study will show that Article 3 , even as reduced, is technically inferior to the N. I. L.91

Article 4, Bank Deposits and Collection, is a misnomer. It is really a Bank Collection statute. The sections on the rights of customers and depository banks are only eight in number and consist largely of detailed rules governing the rights of the banks in collection transactions. The general relations of banks and customers are almost entirely omitted as they might properly be because they seldom involve interstate transactions. But even as a bank collection act only, it is a much needed statute and a vast improvement upon the bankers association "Bank Collection Code" now enacted in about twenty states. It might be well to disconnect this article and adopt it as a uniform law even if the "Code" were not finally recommended.

Article 5 covers twenty-six sections codifying letters of credit and seems pretty well to cover the subject.

Article 6, Miscellaneous Banking Transactions, covers only thirteen sections and is just what it says-"Miscellaneous."

Article 7 , forty-four sections, is a consolidation of the Bills of Lading and Warehouse Receipts Acts and provisions of the Sales Act, which was easy to do because all three of the statutes were practically identical, but because of wholesale changes in language it is doubtful whether it is as good as the original three acts.

Article 8, Investment Securities, in thirty-seven sections, covers much of the material now in the Uniform Stock Transfer Act, and applies the same principles to stocks and bonds whether registered or not. It is a worth-while attempt at codification in this important field but as indicated by some of the examples above it is far from perfection. It has probably oversimplified too many complicated commercial institutions; and in connection with Section I-IO7, as indicated below, puts an intolerable straitjacket on finance transactions.

Article 9, Secured Transactions, is the gem of a great idea already pretty well covered by the not very widely adopted Uniform Conditional Sales Act. It is an attempt to gather under one heading all types of security transactions but it is still too fragmentary and detailed to be offered as a code. There are also grave doubts whether the devices offered for secured transactions are sufficiently various to meet the requirements of the business world. Much more research along these lines is indicated. Here again Section I-IO\%, as indicated below, taken in conjunction with an inadequately codified law, would play havoc in the business world.

Article ro is just another Bulk Transfer Act of which there are many now on the books. It is not important as a uniform law because there is little interstate business involved in this type of transaction.

Taken as a whole this "Code" is a collection of nine statutes, three of whichSales, Negotiable Paper, Documents of Title-covering 60 per cent of its pages are

\footnotetext{
${ }^{01}$ Some studies leading to this conclusion have already been published: Palmer, Negotiable Instruments
} under the Uniform Commercial Code, 48 Micr. L. ReV. 225, 310 (1950). 
now uniformly adopted in as good or better form and in much more usable language than the present draft. Of the remaining six statutes, two, Miscellaneous Banking Transactions and Bulk Sales, are of no partciular significance. The other four, constituting 35 per cent of the "Code" by volume-Letters of Credit, Bank Collections, Investment Securities, and Secured Transactions-are a real and needed addition to uniform laws. In the proper form they would constitute the most valuable contribution of the "Code" to current law.

\section{$\mathrm{V}$}

\section{Authoritative Provisions for INTERpretation}

Article I of the "Code," General Provisions, in addition to definitions already discussed, contains a number of sections of general applicability usually found in uniform statutes; but in addition it embodies, in Part $I$, a number of provisions dealing with statutory construction which are unique in the history of codification in that they attempt to set up a fragmentary technique of interpretation. While many cases in the practice of interpreting uniform laws have appeared, and some generalizations along this line can be made, ${ }^{82}$ it is doubtful if the subject is ready for codification, at least on the broad and dogmatic scale attempted in some of these sections. This effort to straitjacket the courts in application of the statute has already been harshly criticized by a renowned expert on codification. ${ }^{03}$ Little need be added here except to point out the practical results of some of these provisions.

Section I-I02 for example provides: "A provision of this Act which is stated to be applicable between 'merchants' or otherwise to be of limited application need not be so limited when the circumstances and underlying reasons justify extending its application." This section is much broader than the usual analogical interpretation applied properly to codes in that it attempts to empower the courts to extend or repeal sections of this statute when the judges feel justified in doing so. It is clearly unconstitutional in all jurisdictions of the continental United States which have sharp separation of powers, ${ }^{94}$ in that it is a direct delegation of legislative powers to the judiciary. It might also fail as such a delegation simply from vagueness. Even if by some chance the section were to be held constitutional it is doubtful whether the courts would accept the power, and if they would it would be fatal to uniformity because it gives the court power to change statutory rules of law "when the circumstances and underlying reasons justify" it.

Section I-105, with its alternate state and federal versions, which is far too long and complicated to reproduce here in detail, is a fantastic attempt in one section to repeal the conflict of laws as it applies to this subject. Roughly it provides that whenever a transaction whose subject matter is covered by this "Code" in any way

${ }^{92}$ See Beutez's Brannon Negottable Instruments LAw c. V (I950).

${ }^{93}$ Rabel, stipra note 89 , at $428 \mathrm{ff}$.

24 There are about thirty such states. See Frankfurter and Davidson, Cases on Administrative Law, App. I (C), and also (B) and (D) (I935). 
touches the forum, this "Code" shall apply. Not only is it in "disregard of every known system of conflict of laws" $"$ but if ever enacted it would be the destruction of uniformity; and would continually raise the spectre of choice of forum which is the bane of the existence of practicing lawyers and businesssmen alike. The draftsmen glibly justify this exception by a naive argument about as follows: "It is a good code so let's apply it in all possible cases." Although one might doubt the major premise, the practical results of adopting such an argument would be disastrous. Take for example a hypothetical case. A merchant in New York buys goods in San Francisco giving a negotiable note payable in thirty days. The San Francisco vendor discounts the note at his bank. The maturity date passes and nothing happens. The "Code" is not in effect in either state; but, in the process of collection, the note is indorsed in Chicago where the "Code" has been enacted. If the note was in fact dishonored, the merchant, in San Francisco, discharged from his liability as indorser by lack of notice under the N. I. L. both by the law of New York and of California, may find himself held in a suit in Chicago at any time within the statute of limitations under the provisions of Section I-IO5 (3) ${ }^{96}$ because absence of notice is not a defense under the "Code."97 Such a result is probably unconstitutional because it is contrary to the full faith and credit clause of the Federal Constitution.

The whole of Section I-I05 is obviously a club to force adoption of the "Code" in all states, but if the "Code" were so adopted that would not end the difficulty. The history of well-drafted uniform laws such as the Sales Act and Negotiable Instruments Law has shown that interpretation of the best language (to say nothing of the extra difficulties made certain by the exotic phraseology in this "Code") is bound to reach conflicting results in various states. With a provision such as Section I-I05, then legal advice will be impossible because it will have to take into consideration court decisions interpreting the "Code" where it could not even have been foreseen that the law would apply, simply because of a fortuitous routing of shipment, collection, and like transactions beyond the control of the principal parties to the original contract. When it is understood that practically all of the transactions which this "Code" will cover involve interstate commerce, and that it may never be uniformly adopted in all states, the potentialities of mischief for this section are legion. The practical effect would be that each statutory or judicial departure from the uniform rule in any state would be potentially multiplied by the number of other states touching its transactions. This would be the death of uniformity.

But for sheer presumptuousness and impossibility of administration Section I-IO7 takes all of the prizes. ${ }^{98}$ It provides:

${ }^{05}$ Rabel, supra note 89 , at 428.

${ }^{06}$ 1-105(3): "The Articles on Commercial Paper (Article 3) and Bank Deposits and Collections (Article 4) apply whenever any contract or transaction within the terms of any one of the Articles is made or occurs after the effective date of this Act and the contract

(a) is made, offered or accepted or the transaction occurs within this state; or

(b) is to be performed or completed wholly or in part within this state; or

(c) involves commercial paper which is made, drawn or transferred within this state."

or $3-50 x$.

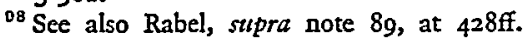


The rules enunciated in this Act which are not qualified by the words "unless otherwise agreed" or similar language are mandatory and may not be waived or modified by agreement.

So far as the writer knows this has no counterpart in modern legislation. It has always been the most effective argument against codification that it created inflexible rules of law, and this in spite of the fact that statutes in all free countries, except where particular sections of the enactments themselves provide that they are mandatory, are construed to mean that codified rules of law can be varied or waived by written agreement of the parties. This "Code" under Section I-I07 makes variations by agreement an exception to the general rule. Surely the draftsmen are not so omnipotent that they can set up a pattern of law governing our complicated commercial world which can be mandatory for the parties in all cases except those which the draftsmen have considered for exclusion. A single example will show the rigidity of this provision. With minor exceptions ${ }^{99}$ it seems impossible as the "Code" now stands for a businessman to issue a "security"100 and make it non-negotiable"101 even if it so provides on the face of the contract. ${ }^{102}$ Such arrangements put an intolerable straitjacket on the business world.

There is however an even further difficulty with this section which lies in the ambiguity of the term "mandatory" itself. Good statutes cannot be drafted in terms of mandatory and nonmandatory. There are at least fourteen degrees of compulsion that may be found in statutes and almost all of them are exemplified by provisions of this "Code" or other uniform statutes. Roughly they are as follows: ( 1 ) Mandatory, act must be done with criminal penalty for refusal. ${ }^{103}$ (2) Mandatory, act must be done, no criminal liability but civil liability. ${ }^{104}$ (3) The act prohibited on criminal penalty. ${ }^{105}$ (4) Act prohibited on civil penalty. ${ }^{108}$ (5) Form required if you want certain results under provision of law. ${ }^{107}$ (6) Mandatory, but a choice between means used for getting results. ${ }^{108}$ (7) Form necessary for the results desired but can be changed by the parties. ${ }^{109}$ (8) Results follow in absence of agreement. ${ }^{110}$ (9) No results without agreement to the contrary, but can be changed by the parties. ${ }^{111}$ In addition to prohibited acts such as (3) and (4) above, (ro) the act may not be prohibited but civil penalties follow. ${ }^{112}$ (II) The act may not be prohibited but results in civil penalties which can be changed by contract.118 (I2)

${ }^{90}$ For example 8-202(5).

1008 -102(1). $\quad{ }^{101} 8-30 \mathrm{r}(3)$ and note.

102 8-202(4) provides: "All other defenses of the issuer including nondelivery and conditional delivery of the security are ineffective against a purchaser for value who has taken without notice of the particular defense." But cf. 8-204: "A restriction on transfer imposed by the issuer even though otherwise lawful is ineffective unless noted on the security." And note that the sections above cited do not contain the exceptions required by I-ro7.

${ }^{203}$ Requirements for registration in Army draft; none in Commercial Code.

101 B. L. A. II, I4; 7-403 (I) and (3), 7-405(I).

${ }^{108}$ B. L. A. 44-50; W. R. A. 50-55.

${ }^{100} 7-304(I)$ and $(4), 4-103(I)$.

108 3-IIO, 3-IIT.

120 2-325(3), I-105, 2-7I4, 2-715.

107 3-104, 9-302, 9-401.
100 3-120.
111 8-204, 8-208.
213 8-208, 3-407(2)(a).

112 7-402. 
The act is not prohibited but void as to one party. ${ }^{114}$ (13) Liability follows the act only when connected with express intent. ${ }^{115}$ (14) Liability for the act regardless of intent but can be waived if intent to do so is expressed. ${ }^{116}$ The reader can without difficulty add more variations. In the ordinary enforcement of law only the first four listed above are usually spoken of as mandatory and cannot be changed by contract. Now when it comes to applying the provisions of Section I-IO7 which of the other ten are excepted?

It seems clear that the "Code" would be better off if Sections I-I02, I-I05, and I-IO7 were omitted entirely, leaving the courts to use their own judgment in establishing postulates of interpretation for the statute.

The "Code" itself already rejects the rules of Sections I-I05 and I-I07 in whole or in part in Articles $4^{117}$ and $9^{118}$ and in fragmentary places elsewhere. ${ }^{119}$ in addition Articles I-I08 and I-207 provide for partial waiver of Section I-IO\%. Section I-I05 in both versions also stipulates that the parties themselves may agree on the law which applies. These sections allowing waivers of otherwise burdensome provisions put a great premium on sophistication, and provide a means of entrapment for innocent parties. They will also lead to all kinds of errors in interpretation. For example anybody reading Sections I-IO7 and 2-7I4 and 2-7I5 together would conclude that no liquidated damages were available, but on discovery of 2-720 and 2-72I it appears that they are. The N. I. I. has been roundly criticized because conflicting cases arose through the courts failing to read all of its sections together; ${ }^{120}$ but in no place in the N. I. L. are there traps within traps to equal this one, or others that will develop through having parts of the code "mandatory" and parts not, depending upon sections scattered throughout eight hundred pages of printed "Code" and Comment.

Just what is the effect of Section I-I02 described above, giving the courts wide latitude in applying the "Code," upon the mandatory provisions of Section I-Io7?

Merely deleting these obnoxious sections from the "Code" would not be enough. This is especially true in the case of I-I07. Throughout the "Code" there has been an attempt, not fully realized, to state the rules in the light of Section I-I07. Were it deleted, as it must be if freedom of contract in business is to continue, every section of the "Code" will have to be re-examined with a view to returning it to the ordinary usage of statutory draftsmanship. (A large but not impossible task in itself.)

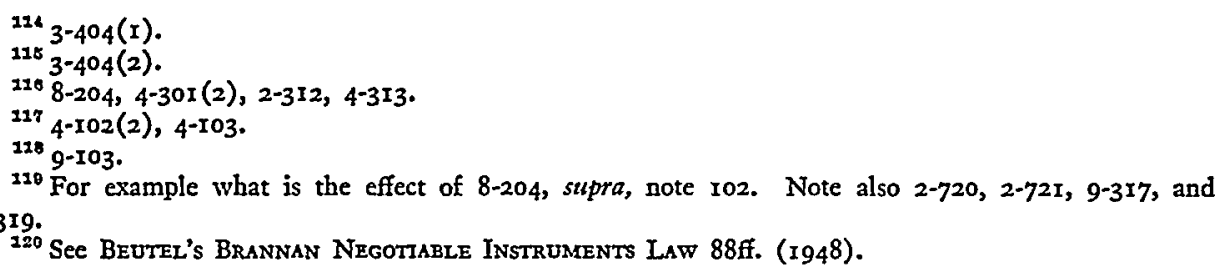




\section{ConcLusions}

The "Code" in its present outline is a worth-while and necessary effort but it is not yet ready for enactment. Unless the present style and draftsmanship are changed it would be much better to print the current uniform laws in a pamphlet and add Articles 4, 5, and 9, revised and enlarged, calling the collection a Commercial Code.

It is possible that the specific defects indicated above could be corrected; and for aught the writer knows, they already may have been eliminated; but these are only samples chosen at random of the results that flow from this kind of codification. The "Code" as a whole must be completely restudied as to language, unity, and style by a committee of top legal experts in the subjects codified, aided by a similar group of commercial experts directing research into the business practices which would be governed and created. Such a revision should be planned to reduce to a minimum the dislocation of law and good business practices by building upon the language and rules of present uniform laws. There should be added to the revised current uniform laws provisions covering the subject matter of Articles 4, 5, and 9 of the current "Code" making such changes and adding such devices as would be proved necessary by careful research into the operation of the law and the needs of business. If this were done there would be built upon the foundations of the current effort a commercial code which would serve the interests of legitimate business throughout the country. To recommend the act in its present form would be to invite chaos and risk possible loss of years of fruitful labor on the present uniform commercial laws. 